ZOOLOGIA 29 (6): 563-576, December, 2012

Available online at www.scielo.br/zool

\title{
Taxonomic reassessment of the treehopper tribe Talipedini with nomenclatural changes and descriptions of new taxa (Hemiptera: Membracidae: Membracinae)
}

\author{
Albino M. Sakakibara \\ Departamento de Zoologia, Universidade Federal do Paraná. Caixa Postal 19020, 81531-980 Curitiba, Paraná, Brazil.
}

\begin{abstract}
The tribe Talipedini Deitz is redefined and its boundaries are expanded with the inclusion of the following taxa: Erechtia Walker, 1858 (formerly placed in Membracini), Pseuderechtia gen. nov. (type species: Leioscyta neivai Fonseca, 1941), and Talipes Deitz, 1975 gen. reval. (formerly junior synonym of Trinarea Goding, 1926, the latter herein considered new synonym of Erechtia). Along with these taxonomic rearrangements, some nomenclatural changes are also introduced. The species treated in this paper are: Erechtia gibbosa (DeGeer, 1773), E. carinata (Funkhouser, 1922) comb. nov., E. cristalta sp. nov. (type locality: French Guyana, Saül), E. diminuta sp. nov. (type locality: Brazil, Pará, Marituba), E. elongatula sp. nov. (type locality: French Guyana, Montagne des Chevaux), E. sallaei (Fowler, 1894), and E. sanguinolenta (Fairmaire, 1846); Pseuderechtia neivai (Fonseca, 1941) comb. nov. = Leioscyta similis Fonseca \& Diringshofen, 1969 syn. nov.; Talipes appendiculatus (Fonseca, 1936) comb. rest. and T. fenestratus (Strümpel, 1974) comb. nov. Due to the inclusion of Erechtia in Talipedini, Tropidoscyta Stål, 1869 is reinstated (in Membracini), and 24 species previously included in Erechtia are considered as incertae sedis within Membracini. A key to genera and new distribution records of the treated taxa are also provided.
\end{abstract}

KEY WORDS. Auchenorrhyncha; Homoptera; nomenclature; taxonomy; treehoppers.

WALKER (1858) created Erechtia to accommodate a single species, Erechtia bicolor, described by him in the same contribution. The few characters he gave to diagnose the genus include: "Body short, broad. Head large. Prothorax convex and hardly keeled in front, with three parallel dorsal keels; the lateral pair abbreviated; the middle one continued to the acute tip". He did not assign the genus to any subfamily or tribe. However, according to the characteristics given, the genus perfectly fits in Membracini, as currently circumscribed.

STÅL (1869) erected Tropidoscyta, defined as having the pronotum with slightly elevated median carina, and with one additional carina on each side. He included eight species in the genus, which were separated by a key. One given couplet is as follows (directly translated from the original Latin excerpt): “d) pronotum with transversal carina anteriorly, between humeral angles, interrupted at middle, parallel to anterior margin; dd) pronotum destitute of transversal carina". The first option indicates T. gibbosa DeGeer. Subsequently, FowLER (1894) designated Membracis torva Germar, 1835 as the type species of Tropidoscyta Stål, 1869.

FunKHOUSER (1922) described Ochropepla carinata in the subfamily Hoplophorinae [sic], characterized as follows: "Small testaceous, a prominent brown carina on each side of median carina and indistinct ridges below these (...). Tegmina subopaque, wrinkled; tip pointed and wrinkled; five apical and three discoidal cells; (...) hind tarsi very much shorter than other two pairs."

Goding (1926), in the key for Hoplophorioninae-Potniini, considered two subgenera in Ochropepla Stål: Ochropepla (s. str.) (with two discoidal cells) and Ochropepla (Trinarea) Goding (with three discoidal cells), and included O. carinata Funkhouser in the latter.

FunKHouser (1927) synonymized Tropidoscyta Stål, 1869 with Erechtia Walker, 1858. As a result, he catalogued 29 valid nominal species in Erechtia.

Deitz (1975) established the tribe Talipedini to include his monotypic genus Talipes Deitz, 1975 (with Tylopelta appendiculata Fonseca, 1936 designated as the type species). He considered this tribe as an intermediate group between Hoplophorionini and Membracini, due to the presence of characteristics observed in both groups.

McKamey \& Deitz (1991) elevated the subgenus Ochropepla (Trinarea) Goding, 1926 to generic rank and, at the same time, treated Talipes as its junior synonym. Therefore, three species were included in Trinarea: T. appendiculata (Fonseca, 1936), T. carinata (Funkhouser, 1922), and T. fenestrata (Strümpel, 1974).

McKamey (1998) presented, in his catalogue, 32 nominal valid species for Erechtia.

MARQUES et al. (2009) listed twelve species of treehoppers collected on "wistletoe", Struthanthus marginatus (Desr.) Blume 
(Loranthaceae), in the state of Bahia. Among them, Erechtia gibbosa (DeGeer, 1773) and Trinarea appendiculata (Fonseca, 1936).

Erechtia, as currently known, is a heterogeneous group in taxonomic disarray. The main goal of this paper is to reassess the taxonomy of the Talipedini, and expand its concept to include several taxa previously placed in Membracini, as well as newly described ones.

\section{Talipedini Deitz, 1975}

Talipedini Deitz, 1975: 40; McKamey \& Deitz, 1991: 195; McKamey, 1998: 215 (cat.). Type genus: Talipes Deitz, 1975.

Body globose, not laterally compressed or tectiform.

Head as long as wide between the eyes, apex deflected; ocelli located above transocular line, equidistant to each other or closer to eyes; posclypeus flattened, in the same plan of vertex, slightly wider than long, apex widely rounded, axe-shaped.

Pronotum convex anteriorly or projected into a short process (only in some females), dorsal contour line somewhat straight or markedly sinuous towards the apex, ornate with the following set of carinae: 1) median carina, percurrent, sharp, strongly keeled on posterior process; 2) one pair of primary lateral carinae converging at the summit of metopidium in frontal view, united or not to median carina, and extended posteriorly above humeral angles towards the lateral margins, not reaching them; 3) 2-3 secondary carinae or rugae located between primary lateral carinae and humeral angles (faint or absent in a few cases); 4) one pair of transversal carinae on metopidium extended from humeral angles towards median carina, parallel to superior margin of head, never united at the middle (conspicuous in Erechtia, wrinkle-like in Trinarea, absent in Pseuderechtia gen. nov., or reduced to short supra-humeral carinae in Talipes); 5) one pair of latero-apical carinae located at distal third of posterior process, each carina parallel and close to lateral margins, reaching median carina at the tip.

Forewings translucent, often pigmented, limbus wrinkled and broad; apex rounded or somewhat pointed (costal-apical margins gradually narrowed into an acute angle, as in Talipes); veins $\mathrm{R}, \mathrm{M}$, and $\mathrm{Cu}$ united at base, vein $\mathrm{R}$ diverging first, $\mathrm{M}$ and $\mathrm{Cu}$ confluent for a short distance; one $s$, two $r-m$, and two $m$ - $c u$ crossveins (three discoidal cells), except for Pseuderechtia, with only one $r-m$ (two discoidal cells). Hindwings transparent, with four apical cells.

Legs with pro- and mesothoracic tibiae spatulate (the latter often feebly foliaceous); metathoracic tibiae usually curved inwards, club-shaped, dilated apically, with cucullate setae in rows I and II (usually reduced in the latter), absent in row III; metatarsi shorter than pro- and mesotarsi.

Abdomen with segments conspicuously punctate dorsally, terga III-VIII with median tuberosities, sternum III with mid-ventral tubercle, sternum IV with transverse keel (Figs 3 and 5). Female with sternum VII widely and deeply emarginated at posterior margin; pygofer large, about as long as all preceding abdominal segments together, visibly flattened ventrally; apex of valvulae slightly exceeding pygofer. Male (Figs 5, 6 and 27) with pygofer small, lateral plate well developed, detached from pygofer; subgenital plate scoop-shaped, apically notched; aedeagus slender, cylindrical, curved upwards, tapering to apex, with minute teeth on the dorsal surface; styles curved distally, hook-like, apex pointed.

Remarks. Talipedini was erected by Deitz (1975) to include solely the type genus, described in the same occasion: Talipes Deitz, 1975, based on Tylopelta appendiculata Fonseca, 1936. It differs from other Membracinae tribes in having a low, more or less globose pronotum, posteriorly tectiform, not foliaceous or laterally compressed; the median carina is prominent and sharp from the top of metopidium to apex of posterior process. The posterior process is triangular and acuminate, with one latero-apical carina at each side that unites with the median carina at the tip. DeIrz (1975) gave the following comments: "Intermediate between the Hoplophorionini and the Membracini, Talipedini has metathoracic legs and female genitalia similar to the former but pro- and mesothoracic legs, pronota, abdomen and male genitalia similar to the latter. The distally clavate metathoracic tibiae are apparently derived from foliaceous forms." As previously stated, all members of Talipedini have a globose pronotum with carinae and rugae, clavate metathoracic tibiae, and reduced tarsi. However, these characters, as mentioned before, are also observed in other Membracinae tribes. The unique morphological feature that defines this tribe is the presence of latero-apical carinae on the posterior process (Fig. 26, la.c.).

Genera included: Erechtia Walker, 1858 (formerly included in Membracini), Pseuderechtia gen. nov., and Talipes Deitz, 1975 gen. reval.

\section{Key to genera}

1 . Forewings with three discoidal cells (with two $r-m$ crossveins) (Fig. 4) 2

$1^{\prime}$. Forewings with two discoidal cells (with one $r-m$ crossvein) (Fig. 26) Pseuderechtia gen. nov.

2. Ocelli closer to eyes than to coronal suture. Pronotum with conspicuous transversal carinae on metopidium (Fig. 2), parallel to anterior margin, from humeral angles towards median carina but interrupted before reaching it (with appearance of faint, wrinkle-like, elevated lines in some cases) Erechtia

2 '. Ocelli closer to coronal suture than to eyes. Pronotum lacking transversal carinae on metopidium, bearing instead a single pair of short supra-humeral carinae (Fig. 35) ........ Talipes

\section{Erechtia Walker, 1858}

Erechtia Walker, 1858: 141; McKamey, 1998: 204 (cat.) [in Membracini]. Type species: Erechtia bicolor Walker, 1858, by monotypy (= Cicada gibbosa DeGeer, 1773).

Hoplophorion (Trinarea) Goding, 1926: 305. Type species: Ochropepla carinata Funkhouser, 1922, by original designation. Syn. nov. 
Trinarea; McKamey \& Deitz, 1991: 195 (= Talipes Deitz, 1975)

[error]; McKamey, 1998: 215 (cat.).

Head (Fig. 2), in frontal view, as long as wide between eyes; ocelli located above transocular line, much closer to eyes than to each other; postclypeus slightly wider than long, extended below margins of vertex about half its length; with apex widely rounded.

Pronotum (Fig. 1) low, somewhat globose, not laterally compressed; median carina percurrent, sharp from top of metopidium to apex; primary lateral carinae equally conspicuous, confluent in front, almost united (clearly united in some cases) with median carina, extended backwards passing well above the shoulders, curved towards lateral margins, and weakened before reaching them at mid-dorsum; apical third of posterior process with a latero-apical carina on each side parallel to lateral margins until reaching tip; transversal carinae on metopidium extended from each humeral angle to median carina, parallel to anterior margin, but not joining each other; 23 small secondary carinae or rugae (variable number) between primary lateral carinae and humeral angles; in lateral view, dorsal contour line evenly descending towards apex of posterior process, sometimes slightly undulate.

Forewings (Fig. 4) translucent, apical limbus broad and wrinkled, with three discoidal cells (one $s$, two $r-m$, and two $m$ $c u$ crossveins).

Legs (Fig. 7) with pro- and mesothoracic tibiae spatulate, barely foliaceous, metathoracic tibiae slightly curved inwards and dilated at apex; cucullate setae on rows I and II (4-5 cucullate setae on the latter); metatarsi slightly shorter than proand mesotarsi.

Abdomen (Figs 3 and 5) and genitalia as described for the tribe.

Remarks. Erechtia was created by WALKER (1858) to include a single species, E. bicolor, described by him in the same contribution. The generic description was vague and indicated features also observed in many other Membracini genera. Due to the superficial resemblance to other membracine groups and the absence of unique diagnostic characters to define the genus, several species have been ascribed to Erechtia throughout the years. As a result, the genus became a highly heterogeneous group that currently comprises 32 species (MCKAMEY 1998).

Erechtia Walker is herein defined by the following features: 1) transversal carinae on metopidium, between humeral angles, more or less parallel to the upper margin of head, interrupted at middle (often reduced to wrinkle-like lines); 2) primary lateral carinae prominent, extended from top of metopidium towards the lateral margins of posterior process; 3 ) apical third of posterior process with a latero-apical carina on each side, parallel to lateral margins (the primary lateral carina is sometimes fused with latero-apical carina forming a single and continuous carina); 4) tegmina with three discoidal cells; 5) legs with prothoracic tibiae not foliaceous, meso- slightly foliaceous, meta- slightly curved and clavate distally, with 4-5 cucullate setae on row II.
Trinarea Goding, 1926 was described as a subgenus of Hoplophorion because of the shape of metatibiae and reduced metatarsi, as observed in members of Hoplophorionini. The genus was probably named after the presence of three discoidal cells in the forewings. McKamey \& Deitz (1991) gave genus status to Trinarea and included it in the Talipedini. Trinarea is herein considered a junior synonym of Erechtia because they share several diagnostic characters. In Trinarea, the transversal carinae on metopidium are very weak, wrinkle-like, and often difficult to be noticed. McKameY (1998) considered Talipes Deitz as a junior synonym of Trinarea. However, Talipes is here treated as a distinct genus.

Species included:

E. gibbosa (DeGeer, 1773)

E. carinata (Funkhouser, 1922) comb. nov.

E. cristalta sp. nov.

E. diminuta sp. nov.

E. elongatula sp. nov.

E. sallaei (Fowler, 1894)

E. sanguinolenta (Fairmaire, 1846)

\section{Erechtia gibbosa (DeGeer, 1773)}

Figs 1-5, 28, 30

Cicada gibbosa DeGeer, 1773: 211 (type loc.: Surinam).

Erechtia gibbosa; McKamey, 1998: 204 (cat.).

Centrotus tricarinatus Fabricius, 1803: 23 (type loc.: South

America); Stål, 1869: 45 (syn.); Funkhouser, 1927: 33;

McKamey, 1998: 204 (cat.).

Membracis poecila Germar, 1821: 24 (type loc.: Brazil). Syn. nov. Tropidoscyta poecila Fowler, 1904: 13.

Erechtia poecila; McKamey, 1998: 205 (cat.).

Membracis tricostata Germar, 1821: 24 (type loc.: Brazil). Syn. nov. Erechtia tricostata; McKamey, 1998: 205 (cat.).

Membracis nigrovittata Fairmaire, 1846: 255 (type loc.: French Guyana, Cayenne). Syn. nov.

Erechtia nigrovittata; McKamey, 1998: 205 (cat.).

Membracis bicristata Fairmaire, 1846: 256 (type loc.: Brazil); Stål, 1869: 45 (syn.); Funkhouser, 1927: 33; McKamey, 1998: 204 (cat.). Erechtia bicolor Walker, 1858: 141 (type loc.: Brazil, Pará: Santarém); Broomfield, 1971: 334; McKamey, 1998: 204 (cat.). Syn. nov. Tropidocyta [sic] guyanensis Buckton, 1901: 54 (type loc.: Guyana). Syn. nov.

Erechtia guyanensis; McKamey, 1998: 204.

Tropidoscyta albipes Funkhouser, 1922: 1 (type loc.: Brazil, Amazonas: Manaus). Syn. nov.

Erechtia albipes; McKamey, 1998: 204 (cat.).

Female (Figs 1-3). Body dull castaneous, covered by silvery short pubescence; head black; pronotum castaneous, in lateral view, usually with U-shaped yellow band extended from top of metopidium, descending towards lateral margins, and ascending to median carina before apex; forewings castaneous at basal half, with small translucent white maculae on claval suture, apical half hyaline; legs yellowish-brown. 
Head (Fig. 2) little wider than long between eyes; eyes globose; ocelli located above transocular line, much closer to eyes and superior margin of head than to each other; postclypeus axe-shaped, wider than long, extended beyond apex of suprantennal ledges about half its length, apical margin widely rounded.

Pronotum (Figs 1, 2 and 4) low, convex anteriorly, metopidium rounded on top; posterior process with dorsal contour line slightly sinuate, apex acute, reaching the middle of fifth apical cell; median carina percurrent, sharp and strong from top of metopidium to apex; primary lateral carinae equally prominent, convergent anteriorly, almost united with median carina on metopidium, extended backwards above humeral angles, weakened and faint near lateral margins at apical third of posterior process; two (rarely three) secondary short carinae, wrinklelike, located between primary lateral carina and humeral angles; transversal carina of metopidium conspicuous (Fig. 2).

Forewings (Figs 1 and 4) punctate on basal half of costal margin and clavus; membrane translucent, microreticulate; apical limbus large and wrinkled; three discoidal cells (with one $s$, two $r-m$, and two $m$ - $c u$ crossveins), five apical cells. Hindwings transparent, with four apical cells.

Legs with pro- and mesothoracic tibiae spatulate, subfoliaceous; metathoracic tibiae slightly curved inwards, somewhat club-shaped, with cucullate setae on rows I and II. Metatarsus reduced, smaller than pro- and mesotarsus.

Abdomen (Fig. 3) and genitalia as described for the tribe.

Male (Figs 4 and 5). Similar to the female, just smaller in size.

Measurements (mm). Female/male: total length 4.50/ 3.44 ; length of pronotum 3.52/2.88; width of head 1.76/1.48; length of head 1.20/1.00; width between humeral angles 2.08/ 1.72 .

Material examined. French Guyana, Montagne Tortue, Sable Blanc, 6/9/2010, 1 male, Lamarre leg.. BraziL, Pará: Utinga, 30/II/1961, 1 male, 1 female, J. \& B. Bechyné leg.; Paraíba: João Pessoa, Campus I UFPB, 27/VIII/1992, 1 male, Creão leg.; Mato Grosso: Sinop, X/1974, 5 males, 1 female, M. Alvarenga; Chapada dos Guimarães, 06/XII/1983, 1 female, Exc. Dep. ZoolUFPR (Polonoroeste); Bahia: Cruz das Almas, IX/2006, 3 females, O.M. Marques leg.; Espírito Santo: Linhares, IX/1972, 2 males, M. Alvarenga leg.; São Paulo: Guarujá, 29/III/1970, 5 males, V.O. Becker leg.. All specimens examined in DZUP.

Distribution. Guyana, French Guyana, and Brazil (AM, PA, PB, MT, BA, ES, SP).

Host plant. Struthanthus marginatus (Desr.) Blume (Loranthaceae) (Marques et al. 2009).

Remarks. The general color is dull castaneous, however it can vary from yellowish-brown to entirely black; the pronotum may be unicolor or bicolor with whitish-yellow maculae or bands; forewings usually with translucent white spots near claval suture. The variation in color is presumed to be the cause for the different species names given by the authors.
STÅL (1869) was the first to consider Centrotus tricarinatus Fabricius, 1803 and Membracis bicristata Fairmaire, 1846 as synonyms of Cicada gibbosa DeGeer, 1773 in Tropidoscyta.

The photographs of the type specimens of Centrotus tricarinatus Fabricius (ZMUC - Zoological Museum, University of Copenhagen - Denmark), Erechtia bicolor Walker (BMNH Natural History Museum, London, UK), and Tropidoscyta albipes Funkhouser (USNM - National Museum of Natural History, Washington, DC) were examined and they confirm the present synonymies.

The types of Membracis poecila Germar, Membracis tricostata Germar, and Membracis bicristata Fairmaire were not seen; the synonymies were based only on the descriptions (and illustration of $M$. bicristata) provided by the authors. In the description of Tropidoscyta sallaei, Fowler (1894) presented the following comments: "Since writing the above I have examined a specimen of Membracis poecila Germ., which is placed in the Vienna Museum collection under Bolbonota. It is closely allied to this genus, but differs in its much slighter pubescence and the almost total absence of carinae above the dorsal ridge of the shoulders."

Tropidoscyta guyanensis Buckton was not examined; the identity of this species was inferred from the original description, and line drawings provided by the author in his monograph (BucкTon 1901, plate VII, figs 4, 4a).

\section{Erechtia carinata (Funkhouser, 1922) comb. nov.} Figs 6-8, 29

Ochropepla carinata Funkhouser, 1922: 11 (type loc.: Brazil, Pará). Trinarea carinata; McKamey \& Deitz, 1991: 195; McKamey, 1998: 215 (cat.).

Female (Fig. 7). Color castaneous; pronotum yellow at middorsum along median carina; space between median carina and primary lateral carinae and apex of posterior process usually darkened; forewings opaque, brown, translucid apically; legs brown.

Head slightly wider than long between eyes; eyes globose; ocelli located above transocular line, closer to eyes than to each other; postclypeus axe-shaped, almost as wide as long, widely rounded at apex.

Pronotum convex in front, with dorsal line of posterior process visibly undulate; median carina percurrent, sharp and strong up to distal apex; primary lateral carina also strong; secondary lateral carinae and transversal carinae of metopidium weak, wrinkle-like, the latter hardly visible or absent in some cases; latero-apical carinae well marked.

Male (Figs 6 and 8). Similar to the female,but smaller and darker. Forewings uniformly dark castaneous.

Measurements (mm). Female/male: total length 6.00/4.80; length of pronotum 5.00/4.00; width of head 2.52/2.08; length of head 1.52/1.12; width between humeral angles 3.12/2.56.

Material examined. French Guyana, Itoupé, DZ $570 \mathrm{~m}$, 11/III/2010, 2 females, 1 male, Saül (Belvedere) ; 9, 23/IX/2010, 

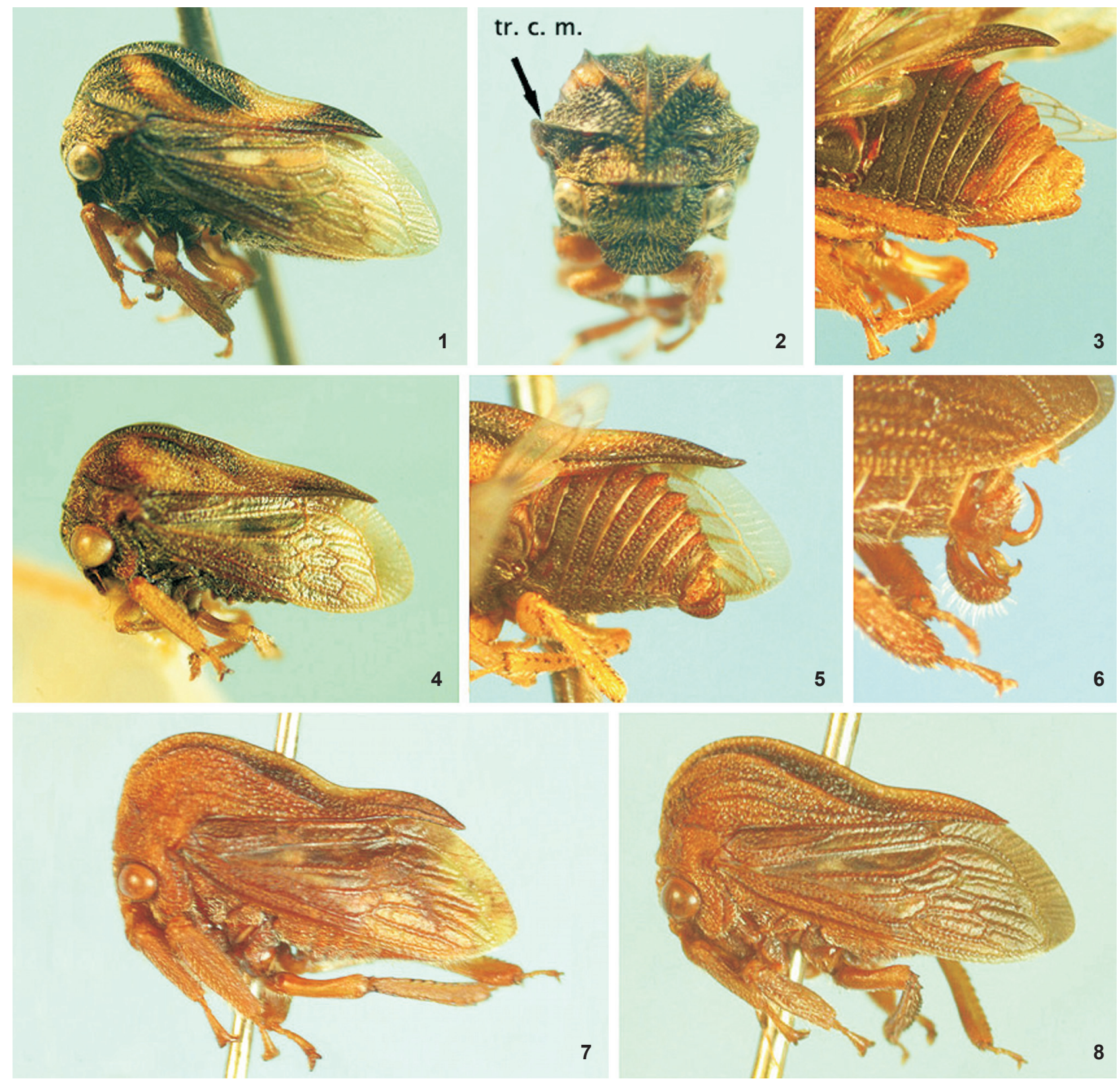

Figures 1-8. Species of Erechtia: (1-5) E. gibbosa: (1-3) female; (4-6) male; (7-8) E. carinata: (7) female; (8) male. (tr.c.m.) Transversal carina of metopidium.

2 males, Vitre leg.; Petite Montagne Tortue, Sable Blanc, 6/IX/ 2010, 1 male, Lamarre leg.; Lassat (Ouest) Terre Firme, 13/IX/ 2010, 1 male. BraziL, Mato Grosso: Chapada dos Guimarães, 24/ XI/1983, 18 females, 30 males, Exc. Dep. Zool.-UFPR (Polonoroeste); Sinop, X/1974, 2 males, M. Alvarenga leg. All specimens examined in DZUP.

Distribution. French Guyana and Brazil (PA, MT).
Remarks. Erechtia carinata is very similar to E. gibbosa, but larger. In E. carinata, the primary lateral carinae and lateroapical carinae are well developed; on the other hand, the transversal carinae on metopidium and secondary carinae above humeral angles are weak, wrinkle-like (the latter absent in some specimens, but usually more developed in males). In E. gibbosa, all carinae are strong and conspicuous. 
FunkHouser (1922) added the following comments at the end of his description: "Small, testaceous, a prominent brown carina on each side of median carina and indistinct ridges below these; body elongate; posterior process reaching just beyond internal angles of tegmina, but not to end of abdomen; tegmina mottled testaceous and brown; under surface of body brown; legs luteous."

A photograph of the female holotype (USNM - National Museum of Natural History, Washington, DC) was seen (Fig. 29).

\section{Erechtia cristalta sp. nov.}

Figs 9-11

Diagnosis. Pronotum dull castaneous, with irregular dirty yellow areas on metopidium, humeral angles and mid-dorsum of posterior process; forewings castaneous, opaque, with small translucent area near base of clavus. Legs yellow.

Female. Head black; pronotum ferrugineous, black on median carina until mid-length, on primary lateral carinae, and apex of posterior process; forewings castaneous at base of costal margin and clavus; membrane smoky-castaneous, with a small translucent white spot at middle of claval suture; legs ferrugineous.

Head (Fig. 10) wider than long between eyes; eyes globose; ocelli located above transocular line, closer to eyes than to each other; postclypeus flattened, axe-shaped, wider than long, extended beyond margins of vertex for about half of its length, apex widely rounded.

Pronotum, in lateral view, with metopidium vertical, rounded above humeral angles, then descending in slight undulation towards apex; median carina strong and sharp after mid-dorsum; primary lateral carinae strongly elevated above humeral angles, forming almost horn-like process; secondary carinae weak (1), wrinkle-like; transversal carinae of metopidium wrinkle-like but well visible; latero-apical carinae conspicuous.

Other characters as described for the genus.

Male. Unknown.

Measurements (mm). Female: total length 4.92; length of pronotum 4.24; width of head 2.20; length of head 1.20; width between humeral angles 2.60.

Holotype, female: "GUYANE FRANÇAISE | Saül - VPV (Belvedere) | 29/X/2010 - vitre" (MNHN - Muséum national d'Histoire naturelle - Paris).

Remarks. This species is quite different from the others. The pronotum is relatively low, but the primary lateral carinae are well developed, expanded above humeral angles in a projection that closely resembles supra-humeral horns, in frontal view. This species is known from a single female specimen.

\section{Erechtia diminuta sp. nov.}

Figs 12-14

Diagnosis. Small; entirely yellowish-castaneous; pronotum with lateral primary carina tinted with black near humeral angles; without secondary lateral carinae.
Female (Figs 12 and 13). Color yellowish-brown; pronotum with primary lateral carinae tinted with black at its highest point; forewings clear and translucid.

Head wider than long between eyes, slightly convex; eyes globose; ocelli located above transocular line, closer to eyes than to each other; postclypeus flattened, axe-shaped, wider than long, extended beyond margins of vertex a little less than half its length, apex widely rounded.

Pronotum, in lateral view, with metopidium vertical, rounded above humeral angles, slightly sinuous and descending towards apex; dorsal carina sharp; primary lateral carinae equally sharp as median carina, extended until near lateral margins; secondary carinae absent; transversal carinae of metopidium feeble, resembling a thin line; latero-apical carinae weakly marked.

Other characters as described for the genus.

Male (Fig. 14). Similar to the female, just smaller; transversal carinae of metopidium obsolete, hardly visible.

Measurements (mm). Female/male: total length 4.40/3.80; length of pronotum 3.60/3.00; width of head 1.92/1.72; length of head 1.20/1.00; width between humeral angles 2.20/1.88.

Holotype, female: "Brasil, PA |J. \& B. Bechyné" "Marituba | 23.6.1961". Paratypes: 1 female, "Brasil, PA | J. \& B. Bechyné" "Icoraci | 4.II.1961"; 1 male, "SINOP - MT - Brasil | S 12³1'- W 55³7'| X/1974 - M. Alvarenga"; 1 female, "Vilhena, RO | 19/XI/ 1986 | C. Elias leg. | POLONOROESTE"; 1 female with the same label data, except |27/12/1986. Types in DZUP (Departamento de Zoologia-UFPR, Curitiba).

Remarks. This species is similar to E. carinata in the general aspect, but much smaller and yellow. The secondary carinae above humeral angles and transversal carinae of metopidium are not visible in females; in males only the transversal carinae is present.

\section{Erechtia elongatula sp. nov. Figs 16-18}

Diagnosis. Pronotum castaneous, black between dorsal carina and primary lateral carinae; forewings castaneous, opaque, slightly pointed at apex. Male entirely black, with dorsal carina brownish-yellow.

Female (Figs16 and 17). Color castaneous; pronotum with area between dorsal carina and primary lateral carinae black; forewings with $\mathrm{C}+\mathrm{Sc}$ and $\mathrm{R}$ red at base, membrane smokycastaneous.

Head (Fig. 17) slightly wider than long between eyes; eyes globose; ocelli located above transocular line, closer to eyes than to each other; postclypeus flattened, axe-shaped, wider than long, extended beyond margins of vertex for about half of its length, apex widely rounded.

Pronotum, in lateral view, with metopidium vertical, rounded above humeral angles, then descending almost straight towards apex; dorsal carina strong and sharp; primary lateral carinae prominent until near lateral margins; secondary carinae weak 

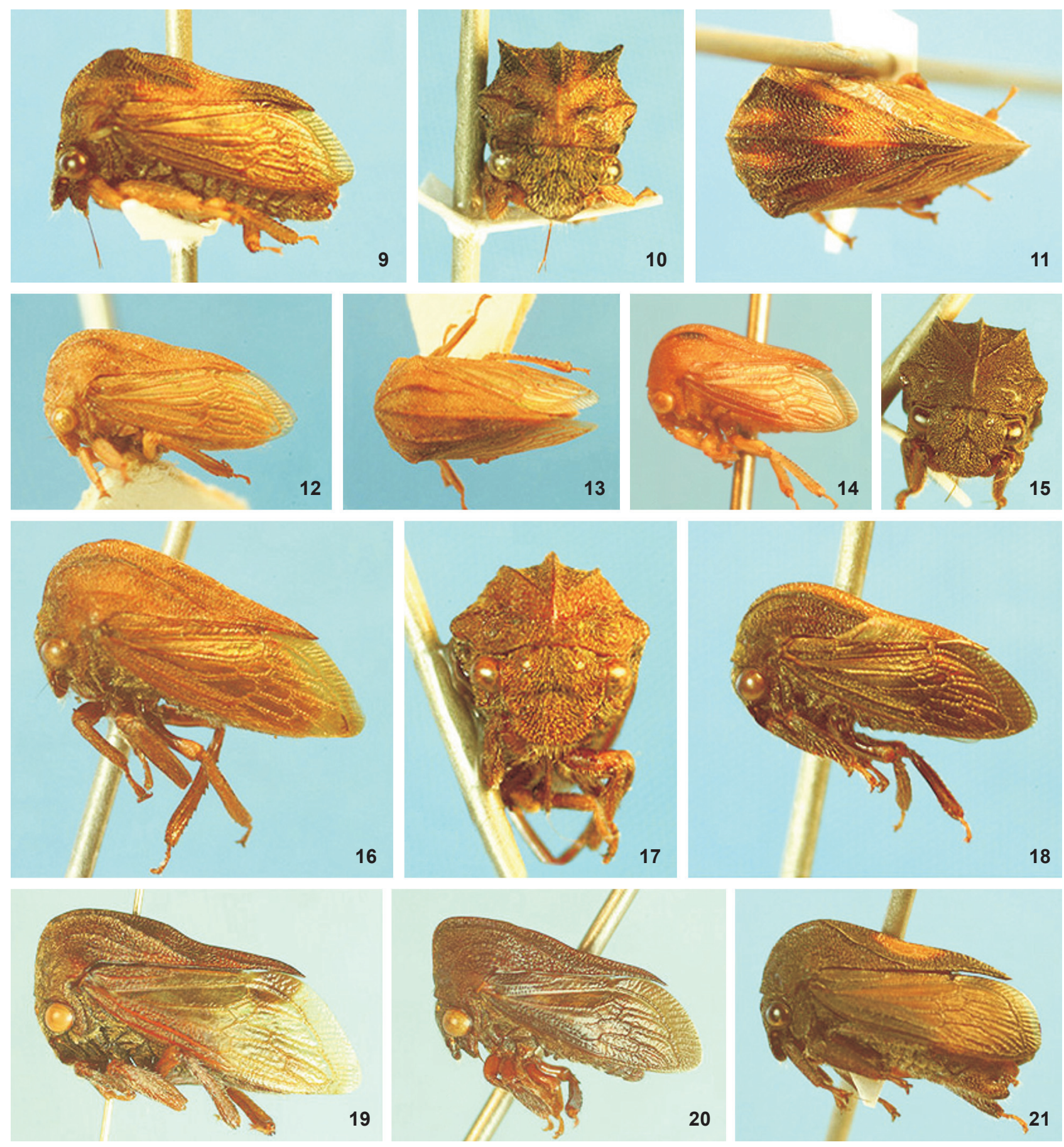

Figures 9-21. Species of Erechtia. (9-11) E. cristalta sp. nov.; (12-14) E. diminuta sp. nov.: (12-13) female; (14) male; (15) E. sanguinolenta, female; (16-18) E. elongatula sp. nov.: (16-17) female; (18) male; (19-20) E. sallaei: (19) female; (20) male; (21) E. sanguinolenta, female.

(2), wrinkle-like; transversal carinae of metopidium faint; lateroapical carinae well marked, almost united to primary carinae. Forewings slightly pointed at apex.
Other characters as described for the genus.

Male (Fig. 18). Similar to the female, a little smaller; color black, with dorsal carina brownish-yellow. 
Measurements (mm). Female/male: total length 5.72/4.60; length of pronotum 4.60/3.60; width of head 2.32/1.88; length of head 1.48/1.16; width between humeral angles 2.76/2.20.

Holotype, female: "GUYANE FRANÇAISE | Montagne des Chevaux | RN2PK22 | 24/II/2008 | (lumineux) - S.E.A.G." (MNHN - Muséum national d'Histoire naturelle, Paris). Paratype: 1 male, with the same label data as holotype (DZUP - Departamento de Zoologia-UFPR, Curitiba).

Remarks. This new species closely resembles E. carinata, from which it differs by the smaller body size, with dorsal contour line almost straight from top of metopidium to apex of posterior process. The dorsal and primary lateral carinae are much stronger. The apex of forewings is tapered, more conspicuously pointed in comparison to other species; this character makes the body seemingly more elongate.

\section{Erechtia sallaei (Fowler, 1894)}

Figs 19-20

Tropidoscyta sallaei Fowler, 1894: 13 (type loc.: Panama, San Feliz); Broomfield, 1971: 373 (lectotype, female). Erechtia sallaei; McKamey, 1998: 205 (cat.).

Tropidoscyta uniformis Fowler, 1894: 14 (type loc.: Panamá, Boquete), Broomfield, 1971: 383 (lectotype, male). Syn. nov. Erechtia uniformis; McKamey, 1998: 206 (cat.).

Fowler's description: "Short, broad in front, much narrowed behind, fusco-ferrugineous or ferrugineous, with the apical portion of the tegmina abruptly hyaline and the apex mucronate. The central carina and one or two on each side are strongly marked, and over each eye there are several small carinae; the metopidium, if viewed from the side, is almost straight, but projects a little further forward at its highest point in some specimens than in others; the surface of the pronotum is clothed with rather spare yellowish pubescence, and is moderately strongly punctured; the legs are fuscous. Long. 5 millim.: lat. max. 3 millim."

Additional characters observed:

Female (Fig. 19). Pronotum chocolate-brown; forewing with costal margin reddish-brown, membrane hyaline, with a round dark smoked spot at apex of clavus extended to limbus. Legs brown.

Head wider than long between eyes; eyes globose; ocelli located above transocular line, closer to eyes than to each other; postclypeus flattened, axe-shaped, wider than long, extended beyond margins of vertex about half its length, apex widely rounded.

Pronotum with median and primary lateral carinae strong, all three united on top of metopidium; secondary lateral carinae (2-3) weak, wrinkle-like; transversal carinae of metopidium not present.

Other characters as in E. carinata.

Male (Fig. 20). Similar to the female, slightly smaller; color black, including forewings. Pronotum distinctly angulate in front, or strongly produced forwards. Forewings entirely smoky-brown.
Fowler's description for Tropidoscyta uniformis: "Very like the preceding [T. sallaei], but smaller and shorter, black or almost black in colour, with the pronotum very coarsely punctured, and with the lateral carinae above the eyes strongly marked; the tegmina are entirely fuscous, with the apex not hyaline, though slightly lighter than the base; the legs are fuscous. Long. 4 millim.: lat. max. $21 / 2$ millim."

Measurements $(\mathrm{mm})$. Female/male: total length $5.80 /$ 4.80; length of pronotum 4.48/3.92; width of head 2.32/1.92; length of head 1.28/1.08; width between humeral angles 2.72/ 2.32 .

Material examined. Costa Rica, Turrialba: 15/VII/1971, 2 males, V.O. Becker leg. Ibidem, 600 m, 25/X/1971, 1male, V.O. Becker leg.; Ibidem, Volcan Turrialba, 1500 m, VIII/1981, 2 females, V.O. Becker leg. All examined specimens in DZUP.

Distribution. Mexico, Guatemala, Panama, and Costa Rica.

Remarks. This species is very similar to $E$. carinata in body size and shape, but is slightly darker. The pronotum is somewhat projected forwards, especially in males, does not form a process or horn. The primary lateral carinae are confluent on top of the metopidium, and united to each other and to the median carina. The transversal carinae of metopidium are much reduced, and cannot be noticed in some specimens.

Tropidoscyta uniformis Fowler, 1894 is here considered a junior synonym of $E$. sallaei Fowler; the first was described from a male specimen, and the second was based on a female. According to the material studied, the description given for $T$. uniformis corresponds to the male of E. sallaei. The photographs of both type specimens (in BMNH - The Natural History Museum, London) were seen.

\section{Erechtia sanguinolenta (Fairmaire, 1846)}

Figs 15,21

Membracis sanguinolenta Fairmaire, 1846: 255 (type loc.: French Guyana, Cayenne).

Erechtia sanguinolenta; McKamey, 1998: 205 (cat.).

Female. Body black; pronotum dark castaneous with an orange-yellow spot on median carina; forewings dark castaneous, opaque, slightly translucid at apex; legs dark castaneous, tarsi yellowish-brown.

Head wider than long between eyes; eyes globose; ocelli located above transocular line, closer to eyes than to each other; postclypeus flattened, axe-shaped, wider than long, extended beyond margins of vertex for about half its length, apex widely rounded.

Pronotum, in lateral view, with dorsal contour line evenly descending to apex of posterior process, almost straight; median and primary lateral carinae strong and sharp; secondary lateral carinae very weak, resembling faint elevated lines; transversal carinae of metopidium and latero-apical carinae conspicuous (the former carinae are short).

Other characters as in E. carinata. 
Male. Unknown.

Measurements (mm). Female: total length 5.28; length of pronotum 4.48; width of head 2.00; length of head 1.20; width between humeral angles 2.60.

Material examined. "GUYANE FRANÇAISE. | Saül - VPV (Belvedere) | 30/9/2010 - P/Vitre (1 female)". In DZUP.

Distribution. French Guyana.

Remarks. This species is morphologically similar to $E$. carinata in the overall aspect. The whole body is black, instead of castaneous. In lateral view, the dorsum is practically straight from top of metopidium until apex of posterior process; in $E$. carinata the dorsum is sinuate. The lateral secondary carinae are absent.

Only one female specimen was examined; its black color with an orange-yellow spot on dorsum corresponds to Fairmaire's description; the collection locality is also the same.

\section{Pseuderechtia gen. nov.}

Figs 22-27

Type species: Leioscyta neivai Fonseca, 1941.

Head (Fig. 23) longer than wide between eyes; eyes globose; ocelli located above transocular line, much closer to eyes and superior margin of head than to each other; postclypeus flattened, axe-shaped, slightly longer than wide, extended below margins of vertex about half its length; widely rounded apically.

Pronotum (Fig. 22), in lateral view, with superior contour line somewhat undulate, slightly elevated after humeral angles; median carina percurrent, sharp and strong on posterior process, almost foliaceous; primary lateral carinae also prominent; secondary lateral carinae (2), weak, wrinkle-like, absent in some specimens; transversal carinae on metopidium absent; latero-apical carinae distinct (Fig. 26, 1a.c.).

Forewings (Figs 22 and 23) coriaceous at base of costal margin and base of clavus; membrane opaque, micro-reticulate, more translucid at apex; limbus broad and wrinkled; with two discoidal cells (with one $s$, one $r-m$, and two $m$ - $c u$ crossveins).

Legs (Figs 22 and 24) with pro- and mesothoracic tibiae spatulate; metathoracic tibiae club-like, cucullate setae on rows I and II; tarsi reduced, smaller than pro- and mesotarsi.

Abdomen (Fig. 27) and genitalia as described for the tribe.

Remarks. This new genus is very similar to Erechtia, but larger and robust. The main difference between these genera is the presence of two discoidal cells in the forewings of Pseuderechtia (with single $r-m$ crossvein). The pronotum is similarly carinate; the median carina is distinctly more flattened and elevated on posterior process; secondary lateral carinae are feeble, sometimes absent; the transversal carinae on metopidium are absent; latero-apical carinae are conspicuous.

Species included: Pseuderechtia neivai (Fonseca, 1941) comb. nov.

\section{Pseuderechtia neivai (Fonseca, 1941) comb. nov.} Figs 22-27

Leioscyta neivai Fonseca, 1941: 129 (type loc.: Brazil, São Paulo: Guarujá); McKamey, 1998: 208 (cat.).

Leioscyta similis Fonseca \& Diringshofen, 1969: 147 (type loc.: Brazil, Acre); McKamey, 1998: 208 (cat.). Syn. nov.

Characters as given for the genus.

Female (Fig. 22). Brown color; pronotum with two translucid yellowish spots on median carina, in sequence, one at base and other at apical third of posterior process. Forewings opaque, basal costal margin and clavus castaneous; clear translucid at middle and hyaline at apical third; a transversal row of castaneous spots (2-3) at middle, and a smoky-castaneous band at apical third, broadened at apex of clavus and extended over part of limbus. Legs castaneous, tarsi yellow.

Male (Figs 24 and 27). Similar to the female, smaller, usually darker.

Measurements. Female/male: total length 5.20/4.40; length of pronotum 4.40/3.80; width of head 1.92/1.68; length of head 1.40/1.20; width between humeral angles 2.60/2.28.

Material examined. Ecuador, Napo: Misahualli, 19/II/1983, 1 male, 3 females, L. Huggert leg. ( LUND); Campana Cocha, 8/ VII/1984, 2 females (LUND). Peru, Madre de Dios: Puerto Maldonado, 9/I/1984, 2 females, L. Huggert leg. (LUND); Huanuco: Tingo Maria, 27/I/1984. 1 male, L. Huggert leg. (LUND). BraziL, Goiás: Planaltina, 1000 m, 20/IV/1976, 18 males, 51 females, V.O. Becker leg. (DZUP); Mato Grosso: Sinop. X/1975, 1 male, M. Alvarenga leg. (DZUP); Espírito Santo: Parque Sooretama, 27/XI/1967, 1 male, 20 females, F. Oliveira leg. (DZUP); São Paulo: Nova Europa, Fazenda Itaquerê, 25/IV/1968, 1 male, 1 female, K. Lenko leg. (DZUP); Araras, 15/06/83, 2 females, M.B.S. Campos leg. (DZUP); Paraná: Londrina. 14/II/75, 3 females, Pe. Moure \& Rosado leg. (DZUP); Jussara, Horto Florestal 340 m, 1-3/XI/ 1974, 3 females, Exp. Depto. Zoo-UFPR (DZUP).

Distribution. Ecuador, Peru, and Brazil (GO, MT, ES, SP, PR).

Remarks. This species is morphologically similar to $E$. carinata. It differs in having the pronotum with a more developed median carina, which is laminar and almost foliaceous on the posterior process; dorsal contour line straight, but slightly elevated at mid-dorsum; two translucid spots on dorsum; secondary lateral carinae usually weak, wrinkle-like, absent in some specimens; no transversal carina on metopidium; and forewings castaneous, mottled at middle and hyaline at apex, with two discoidal cells (only one $r$ - $m$ crossvein).

FonseCa (1941) included this species in Leioscyta (Membracini) due to the presence of lateral carinae on pronotum and two discoidal cells in the forewings. Leioscyta similis Fonseca \& Diringshofen is here considered as a junior synonym because the only difference pointed out by the authors was the lack of secondary carinae above humeral angles. As observed in this study, this character is subject to great variation.

The photographs of both types were seen. 


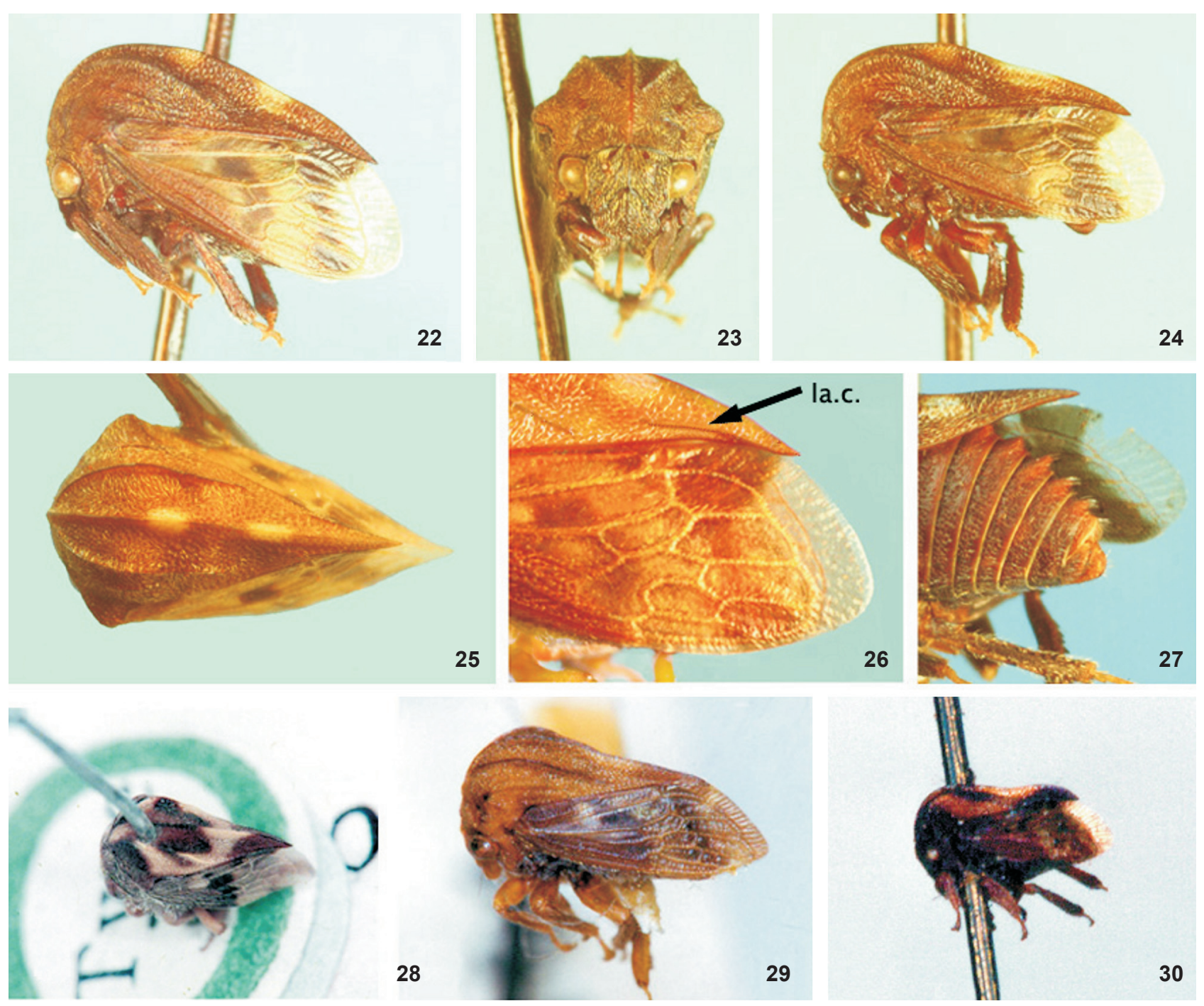

Figures 22-30. Species of Pseuderechtia gen. nov. (22-27) Pseuderechtia neivai: (22, 23, 25, 26) female; (24, 27) male. (28-30). Type specimens: (28) Erechtia bicolor, holotype, female, BMNH; (29) Ochropepla carinata, holotype, female, USNM; (30) Centrotus tricarinatus, syntype, male. (la.c.) Lateral-apical carina.

\section{Talipes Deitz, 1975 gen. reval.}

Talipes Deitz, 1975: 41; McKamey \& Deitz, 1991: 195 = Trinarea Goding, 1926 [error]; McKamey, 1998: 215 (cat.). Type species: Tylopelta appendiculata Fonseca, 1936, by original designation.

Diagnosis (adapted from the original description provided by Deirz 1975). Pronotum convex with longitudinal rugae and carinae, in some females with a short, median anterior prominence; forewing with two $r-m$ and two $m$-cu crossveins; hindwing with $r-m$ crossvein present; pro- and mesothoracic tibiae foliaceous; metathoracic tibiae not foliaceous, clavate distally with cucullate setae on rows I and II but not III; met- athoracic tarsus much shorter than pro- and mesothoracic tarsus; abdomen conspicuously punctuate dorsally; male lateral plate not fused to pygofer, without hook.

Additional characters observed:

Head (Figs 32 and 41) wider than long between eyes; eyes globose; ocelli located above transocular line, almost equidistant to each other and to eyes, closer to superior margin of head; postclypeus slightly convex at middle, axe-shaped, much wider than long, widely rounded at apex.

Pronotum, in lateral view (Figs 31, 34 and 40), with metopidium vertical and median carina on top, slightly projected forwards; posterior process above humeral angles almost 
horizontal, then abruptly sinuate, descending towards apex; median carina sharp, well marked from top of metopidium until posterior apex; primary lateral carinae strong (Figs 32 and 35), parallel to median carina and slightly more elevated above humeral angles, extended from metopidium to lateral margins but not reaching them; secondary lateral carinae (1-2) weak, wrinkle like; supra-humeral carinae short, well marked (Fig. 35, sh.c.); latero-apical carinae conspicuous (Fig. 38, la.c.).

Forewings coriaceous on costal margin and basal half of clavus; membrane opaque, micro-reticulate, translucid, hyaline at apex; limbus wide and wrinkled; three discoidal cells (one $s$, two $m$ - $c u$ and two $r$ - $m$ crossveins).

Legs with prothoracic tibiae spatulate, mesothoracic tibiae foliaceous; metathoracic tibiae club-like, curved inwards, dilated at apex, with tarsi very reduced (Figs 31, 33 and 37).

Abdomen (Fig. 36) and genitalia as described for the tribe.

Remarks. Talipes is very similar to Erechtia in several aspects such as the configuration of carinae and rugae on the pronotum, and forewing venation (with three discoidal cells). In Talipes, the ocelli are equidistant to each other and closer to the superior margin of the head; the postclypeus is wider than long; pronotum with dorsum distinctly undulate, with primary lateral carinae strong and elevated; supra-humeral carinae short and distinct; forewings usually pointed apically, with external angle more acute; and legs with mesothoracic tibiae foliaceous; metatarsi very small, similar to those of the Hoplophorionini.

\section{Talipes appendiculatus (Fonseca, 1936) comb. rest.}

Figs 31-39

Tylopelta appendiculata Fonseca, 1936: 158 (type loc.: Brazil, Pernambuco); Strümpel, 1974: 539.

Talipes appendiculata [sic]; Deitz, 1975: 41.

Trinarea appendiculata; McKamey \& Deitz, 1991: 195; McKamey, 1998: 215 (cat.).

Female (Figs 31, 32 and 36-38). Color castaneous, blackish on head and metopidium until slope of median carina; forewings castaneous with an oblique whitish band crossing the membrane from costal margin to apex of clavus, apex and limbus clear translucid; legs light castaneous.

Pronotum, in lateral view, with metopidium vertical above head, distinctly projected forwards on top, forming a small rounded process; dorsal contour line almost horizontal above humeral angles, then abruptly descending at about apical third, slightly arcuate towards apex; primary lateral carinae strong (Figs 32 and 35), sinuous above humeral angles, higher than median carina, extended posteriorly near lateral margins at mid-dorsum; latero-apical carinae conspicuous (Fig. 38, la.c.); secondary lateral carinae (1-2) very weak, wrinkle-like; suprahumeral carinae small, conspicuous (Fig. 35).

Other characters as in the genus description.

Male (Figs 34 and 35). Similar to the female, smaller, with anterior projection of pronotum much reduced, usually angulate only at the top of metopidium.

Measurements ( $\mathrm{mm})$. Female (with frontal process)/male: total length $4.68(5.20) / 4.12$; length of pronotum 3.60 (4.20)/ 3.40; width of head 2.05 (2.20)/1.80; length of head 1.08 (1.20)/ 1.00; width between humeral angles $2.40(2.64) / 2.20$.

Material examined. Panama, Canal Zone, IV/1976, 1 male. BrazIL, Mato Grosso: Sinop, X/1975, 1 female, M. Alvarenga leg.; Minas Gerais: Buritizeiro, XI/1977, 1 female, Pe. Moure \& Sakakibara leg.; Rio de Janeiro: Silvestre. 4/IV/1960, 1female [with frontal process], M. Alvarenga leg.; São Paulo: Botucatu, 22/V/ 1982, 3 females, A. Scivittaro leg.; Mogi Guaçu, 6/VI/1980, 3 females, B.C.L. Brodosky leg.; 26/XII/1970, 5 males, Pe. Moure leg.; Paraná: Londrina, 29/II/2000, 3 females, AQ.M.Meneguim leg.; Santa Catarina: Nova Teutônia, 29/XI/1952, 3 females, F. Plaumann leg.. All examined specimens in DZUP.

Syntype (Fig. 39) female (MZSP - Museu de Zoologia-USP, São Paulo).

Distribution. Panama, Colombia, Peru, and Brazil (PE, MT, GO, MG, RJ, SP, PR, SC).

Remarks. This species was described by FonseCA (1936) based on a female specimen in which the pronotum is projected forwards in a short process (Fig. 39); the males, on the other hand, lack such process, and exhibit, in some cases, only a slightly angulate tubercle on top of metopidium. STRÜMPEL (1974) examined female specimens from Colombia without this frontal process. Deirz (1975) also commented that he examined some female specimens from Peru in which the short frontal prominence of the pronotum was absent. Several specimens from different localities in Brazil were examined, and all females lacked an anterior process, as described, except for one female from Rio de Janeiro, which otherwise fits perfectly in this species. Thus, this feature is considered polymorphic in the present paper.

\section{Talipes fenestratus (Strümpel, 1974) comb. nov. Figs 40-41}

Tylopelta fenestrata Strümpel, 1974: 538 (type loc.: Colômbia, Meta: Cano Grande).

Trinarea fenestrata; McKamey \& Deitz, 1991: 195; McKamey, 1998: 216 (cat.).

Female. Head brown, with golden-yellow pubescence; pronotum brown; forewings dull brown, irregularly marked with translucent white spots, one on apical limbus.

Pronotum relatively low, metopidium more or less vertical, dorsal contour line almost horizontal for a short distance above humeral angles, then descending slightly sinuous towards apex of posterior process; median carina sharp and keel-like, percurrent from top of metopidium to apex; primary lateral carina strong, more elevated than median carina above humeral angles, reaching mid-lateral margins; secondary carinae (2) short and weak, wrinkle-like; supra-humeral carinae short and conspicuous; latero-apical carinae conspicuous. 

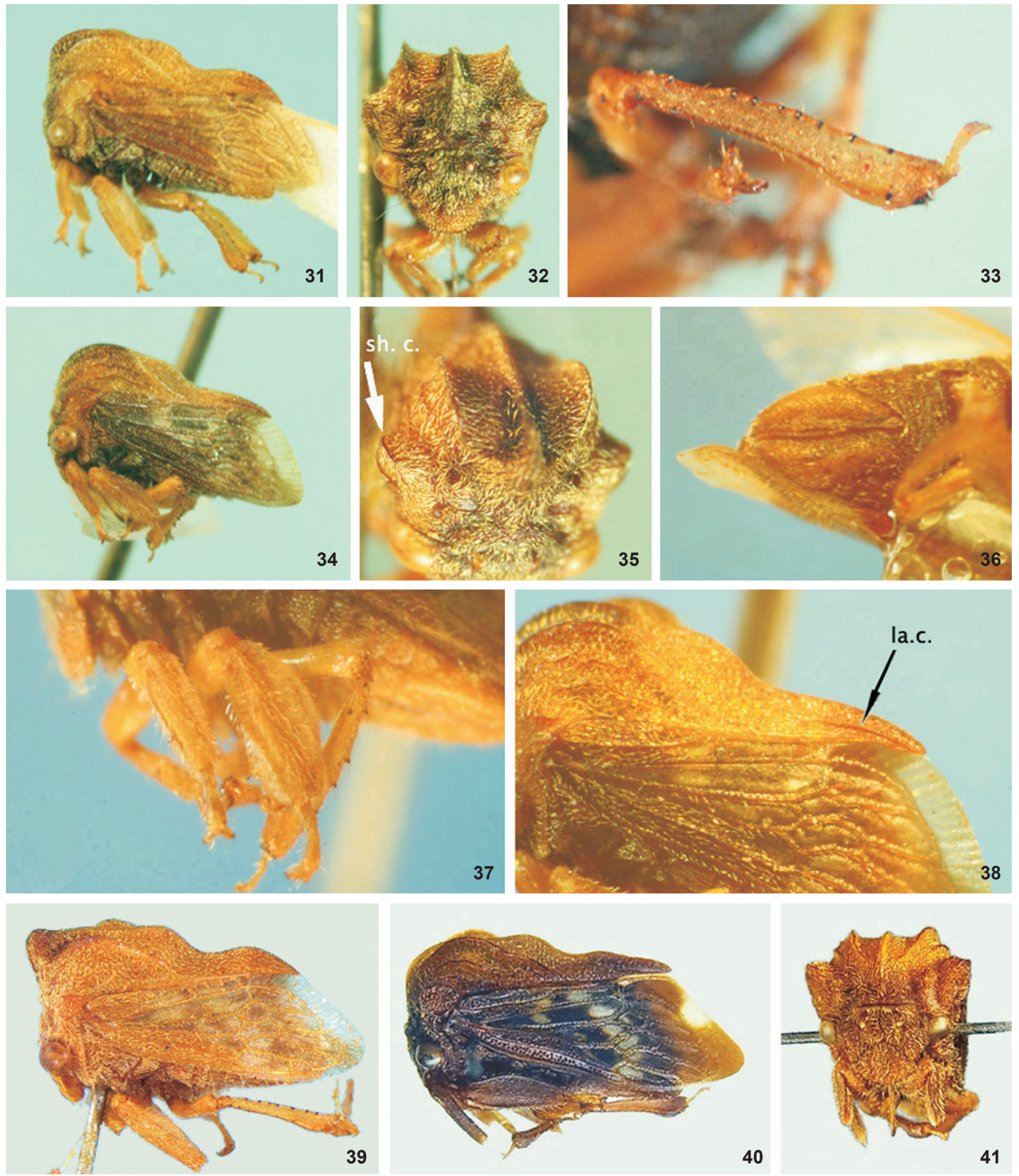

Figures 31-41. Species of Talipes. (31-38) Talipes appendiculatus: (31, 32, 33, 36, 37, 38, 39) Tylopelta appendiculata, syntype, female, MZSP; $(34,35)$ male; $(40,41)$ Talipes fenestratus: Tylopelta fenestrata, holotype, female, ZMUH. (la.c.) Lateral-apical carina, (sh.c.) supra-humeral carina. 
Other characters as in the genus description.

Male. Unknown.

Material examined. Only photographs of the holotype (female from Colombia) were examined. It is deposited in the collection of the ZMUH - Zoologisches Institut und Zoologisches Museum, Universität Hamburg. The photos were kindly provided by Dr. H. Strümpel.

Distribution. Colombia and Peru.

Remarks. This species is similar to T. apppendiculatus. It differs by the color of the body, much darker, with conspicuous translucent white spots on forewings, one of them at the apex, rounded, translucid, extended throughout the width of limbus. This species seems to be more elongate, with the dorsum lower above humeral angles. In this paper, Erechtia Walker is separated from Tropidoscyta Stål, 1869 and transferred to the tribe Talipedini Deitz. With this taxonomic act, Tropidoscyta (previously considered a junior synonym of Erechtia) is reinstated, along with its type species, Tropidoscyta torva (Germar, $1835)$ comb. rest. The remaining species, formerly included in Erechtia according to McKamey (1998) (except for E. gibbosa, E. carinata, E. sanguinolenta, and E. sallaei, together with their respective synonyms, including the new ones), are herein considered as incertae sedis (in Membracini) until their accurate taxonomic position be reassessed. A complete list of taxa presently considered as incertae sedis is provided below.

\section{Membracini}

\section{Tropidoscyta Stål, 1869 gen. reval.}

Tropidoscyta Stål, 1869: 44; Funkhouser, 1927: 32 (cat.) [ = Erechtia Walker, 1858] [error]; McKamey, 1998: 204 (cat.) [ = Erechtia Walker].

Type species: Membracis torva Germar, 1835, subsequent designation by Fowler, 1894.

Tropidoscyta torva (Germar, 1835) comb. rest. Membracis torva Germar, 1835: 228 (type loc.: Brazil). Erechtia torva; McKamey, 1998: 205 (cat.).

\section{Incertae Sedis}

Centrotus abbreviatus Fabricius, 1803: 23

Enchenopa longa Walker, 1851: 486

Enchenopa subtrigona Walker, 1851: 485

Erechtia brevis Goding, 1928: 40

Erechtia gilvitarsi Goding, 1928: 39

Erechtia minutissima Goding, 1928: 40

Erechtia pulchella Goding, 1928: 40

Erechtia trimaculata Fonseca, 1941: 132

Erechtia trinotata Funkhouser, 1930: 412

Membracis carbonaria Germar, 1835: 228

Membracis decipiens Fairmaire, 1846: 254

Membracis maculosa Fairmaire, 1846: 254

Membracis ophthalmica Fairmaire, 1846: 255
Membracis truncata Fairmaire, 1846: 253

Tropidocyta [sic] bulbosa Haviland, 1925: 236

Tropidoscyta binotata Funkhouser, 1914: 359

Tropidoscyta brunneidorsata Funkhouser, 1914: 357

Tropidoscyta immaculata Funkhouser, 1914: 360

Tropidoscyta minor Buckton, 1901: 53

Tropidoscyta minuta Funkhouser, 1922: 1

Tropidocyta [sic] neglecta Haviland, 1925: 227

Tropidoscyta punctipes Buckton, 1901: 53

Tropidoscyta succedanii Buckton, 1901: 53

Tropidoscyta transiens Fowler, 1894: 415

\section{ACKNOWLEDGMENTS}

I thank Stéphane Brule (Société Entomologique de Antilles-Guyane - SEAG) for allowing me to study membracid specimens collected in different localities of French Guyana. To H. Strümpel (Universität Hamburg, Germany) for his kindness in providing the photographs of the type specimen of Talipes fenestratus. Special thanks to Olivia Evangelista for revising the manuscript.

\section{LITERATURE CITED}

Broomfield, P.S. 1971. A catalogue of the membracid types (Homoptera: Membracidae) in the British Museum (Natural History). Bulletin of the British Museum (Natural History), Entomology 25 (8): 327-386.

Buckton, G.B. 1901. A monograph of the Membracidae. London, L. Reeve \& Company, p. 1-92, pls 1-28.

DeGeer, C. 1773. Cinquième mémoire. Des Cigales. Mémoires pour servir à l'Histoire des Insectes 3: 1-696.

Deitz, L.L. 1975. Classification of the higher categories of the New World treehoppers (Homoptera: Membracidae). North Carolina Agricultural Experiment Station Technical Bulletin 225: 1-177.

FABRICIUS, J.C. 1803. Rhyngota. Systema Rhyngotorum secundum ordines, genera, species adiectis synonymis, locis, observationibus, descriptionibus, 314p.

Fairmaire, L. 1846. Revue de la tribu des Membracides. Annales de la Société Entomologique de France 4: 235-320.

FonseCA, J.P. DA. 1936. Contribuição para o conhecimento dos membracídeos Neotrópicos. Archivos do Instituto Bilógico 7 (12): 157-166.

FonsECA, J.P. DA. 1941. Contribuição para o conhecimento dos membracídeos neotrópicos (IV). Arquivos do Instituto Biológico 12 (10): 129-140.

FonseCA, J.P. DA \& R.V. DiRIngShofEn. 1969. Contribuição ao conhecimento dos membracídeos neotrópicos (Homoptera: Membracidae, VI). Arquivos do Instituto Biológico 36 (3): 143-161.

Fowler, W.W. 1894. Order Rhynchota. Suborder HemipteraHomoptera. (Cont.). Biologia Centrali-Americana 2: 1-24. FunkHouser, W.D. 1914. New south American Membracidae. The 
Canadian Entomologist 46: 357-408.

Funkhouser, W.D. 1922. New records and species of South American Membracidae. Journal of the New York Entomological Society 30: 1-35.

FunkHouser, W.D.1927. Membracidae. General Catalogue of the Hemiptera. Northampton, Smith College, Fasc. 1, 581p.

FunKHouser, W.D. 1930. New genera and species of Neotropical Membracidae. Journal of the New York Entomological Society 38: 405-421.

Germar, E.F. 1821. Bemerkungen über einige Gattungen der Cicadarien. Magazin der Entomologie 4: 1-106.

Germar, E.F. 1835. Species Membracidum Musae E. F. Germari. Revue Entomologique Silbermann 3: 223-262.

Goding, F.W. 1926. Classification of the Membracidae of America. Journal of the New York Entomological Society 34: 295-317.

Goding, F.W. 1928. New Membracidae, IV. Journal of the New Yortk Entomological Society 36: 37-41.

Haviland, M.D. 1925. The Membracidae of Kartabo, Bartica District, British Guiana, with descriptions of new species and bionomical notes. Zoologica 6 (3): 229-290.

Marques, O.M.; A.M. Sakakibara; M.J.S. Santana; A.J.A. Carvalho \& M.L. Coutinho. 2009. Espécies de Membracoidea (Insecta:
Hemiptera) associadas a erva-de-passarinho Struthanthus marginatus (Desr.) Blume em Cruz das Almas, Bahia. Magistra 21 (3): 219-221.

McKamey, S.H. 1998. Taxonomic catalogue of the Membracoidea (exclusive of leafhoppers): second supplement to fascicle I - Membracidae of the General Catalogue of the Hemiptera. Memoirs of the American Entomological Institute 60: 1377.

McKameY, S.H. \& L.L. Deitz. 1991. Nomenclatural changes in the treehopper tribes Hoplophorionini, Smiliini, and Talipedini (Homoptera: Membracidae). Proceedings of the Entomological Society of Washington 93 (1): 193-196.

STÅL, C. 1869. Hemiptera Fabriciana. Öfversigt af Kongliga Vetenskaps-Akademiens Förhandlingar 8: 18-58.

StrümPel, H. 1974. Beitrag zur Kenntnis der neotropischen Membraciden Gattung Tylopelta Fowler, 1894. Entomologische Mitteilungen aus dem Zoologischen Museum Hamburg 4: 531-540.

WALKER, F. 1851. List of specimens of Homopterous insects in the collection of the British Museum 3: 637-907.

WALKER, F. 1858. Supplement. List of the specimens of homopterous insects in the collection of the British Museum. London, 307p.

Submitted: 21.VI.2012; Accepted: 19.IX.2012.

Editorial responsibility: Gabriel L.F. Mejdalani 